\title{
Biometric analysis of the maxillary permanent molar teeth and its relation to furcation involvement
}

\section{Estudo biométrico dos molares permanentes superiores e sua relação com envolvimento de furcas}

\author{
Hélio Ferraz Porciúncula* \\ Mariana Machado da Porciúncula** \\ Elizangela Partata Zuza*** \\ Benedicto Egbert Corrêa de Toledo****
}

\begin{abstract}
A high rate of root exposure and consequently the exposure of the furcation area is usually observed in multirooted teeth. In maxillary molar teeth, this fact may endanger the three existent furcations (buccal, mesial and distal), causing serious problems. In this research, distance measures from the buccal furcation to the mesial $(\mathrm{F} 1 \mathrm{M})$ and distal (F1D) surfaces of the mesio-buccal and disto-buccal roots; from the mesial furcation to the buccal (F2B) and palatal (F2P) surfaces of the mesio-buccal and palatal roots and from the distal furcation to the buccal (F3B) and palatal (F3P) surfaces of the disto-buccal and palatal roots, respectively were established. One hundred maxillary first molar teeth were used, 50 of the right and 50 of the left side. Reference marks and demarcations were determined on the furcations and also on the root surfaces involved in the measures. We concluded that these measurements are important because they may effectivelly contribute to diagnosis, prevention and treatment of periodontal problems.
\end{abstract}

DESCRIPTORS: Furcation defects; Molar; Periodontal diseases.

\begin{abstract}
RESUMO: Nos dentes multirradiculares, é comum se observar uma alta taxa de exposição radicular e, conseqüentemente, a exposição da região de furca. Nos molares superiores, esse fato pode afetar as três furcas existentes (vestibular, mesial e distal), ocasionando sérias dificuldades. Nesta pesquisa, foram estabelecidas medidas de distâncias da abertura da furca vestibular em relação às faces mesial (F1M) e distal (F1D) das raízes mésio-vestibular e disto-vestibular; da furca mesial em relação às faces vestibular (F2V) e palatina (F2P) das raízes mésio-vestibular e palatina e da furca distal em relação às faces vestibular (F3V) e palatina (F3P) das raizes disto-vestibular e palatina, respectivamente. Foram utilizados 100 primeiros molares superiores, separados respectivamente em 50 do lado direito e 50 do lado esquerdo. Medidas de referência e demarcações foram realizadas nas furcas e também nas superficies radiculares adjacentes. Concluímos que essas mensurações são importantes porque contribuem eficientemente para o diagnóstico, a prevenção e o tratamento de problemas periodontais.
\end{abstract}

DESCRITORES: Defeitos da furca; Molar; Doenças periodontais.

\section{INTRODUCTION}

Some variations of root anatomy in regard to shape, size and number must be considered as predisposing causes for the appearance and evolution of periodontal diseases, for they are favorable sites for bacterial plaque accumulation. The latter is essential for the development and progression of the disease, menacing not only the alveolar bone, but also periodontal ligaments ${ }^{6,8}$.

In multirooted teeth, the clinical observation of a high rate of root exposure and consequently the exposure of the furcation area is common. In maxillary molar teeth, this fact may endanger the three existent furcations (buccal, mesial and distal), causing serious problems. It is likely that, once the furcation region is affected, the roots will present a greater loss of periodontal insertion than the other parts of the teeth, since plaque control is very poor and difficult in this region. An early diagnosis is fundamental in order to attain success in the control of periodontal diseases ${ }^{11}$.

According to the related dental literature, it is necessary to obtain more detailed knowledge

\footnotetext{
* Professor of Anatomy, Division of Morphology; **Specialist in Periodontology; ***Graduate Student in Periodontology; ****Chairman in Periodontology, Division of Oral Surgery and Diagnosis - School of Dentistry of Araraquara, São Paulo State University.
} 
Porciúncula HF, Porciúncula MM, Zuza EP, Toledo BEC. Biometric analysis of the maxillary permanent molar teeth and its relation to furcation involvement. Braz Oral Res 2004;18(3):187-91.

and systematic measures, which can help in a more accurate understanding of the anatomy of the furcation of multirooted teeth. This piece of information is essential to establish an early diagnosis of periodontal inflammation, thus preventing its progress. Facing such considerations, the authors propose to establish, in this paper, distance measures from:

1. buccal furcation to the mesial and distal surfaces of the mesio-buccal and disto-buccal roots;

2. mesial furcation to the buccal and palatal surfaces of the mesio-buccal and palatal roots;

3. distal furcation, to the buccal and palatal surfaces of the disto-buccal and palatal roots, respectively.

\section{MATERIAL AND METHODS}

The material used in this research consisted of a sample of 100 human maxillary permanent first molars, divided respectively into 50 teeth of the right side and 50 teeth of the left side.

The teeth were selected considering the anatomic integrity in the region of buccal, mesial and distal furcations and also the root region. All the teeth, before being submitted to measurements, were cleansed for removal of debris with extreme care not to affect the areas to be measured. For this procedure, an ultrasonic instrument (Dabi Atlante S.A. Indústrias Médico-Odontológicas, Ribeirão Preto, Brazil), and water, air and a sodium bicarbonate jet (Dabi Atlante S.A. Indústrias MédicoOdontológicas, Ribeirão Preto, Brazil) were used.

Small calculi that were still present were daubed with $2 \%$ muriatic acid (Labsynth Produtos para Laboratórios Ltda., Diadema, Brazil) for 30 minutes and were then totally removed with periodontal curettes (Hu-Friedy, Chicago, USA), bicarbonate jets or the ultrasonic instrument. After total removal of the solid residues, all teeth were immersed in a solution which consisted of distilled water $(1,000 \mathrm{ml})$, hydrogen peroxide 120 volumes $(250 \mathrm{ml})$ (Labsynth Produtos para Laboratórios Ltda., Diadema, Brazil) and ammonium hydroxide P.A. $(50 \mathrm{ml})$ (Labsynth Produtos para Laboratórios Ltda., Diadema, Brazil), in order to bleach the teeth, as well as to remove any superficial stains.

The teeth were kept in this solution for 24 hours and were then washed in tap water. Once this last procedure was performed, the teeth were immersed in acrylic resin chemically polymerized (Artigos dentários Clássico, SP, Brazil).

The immersion of the teeth in resin was performed as follows: the first molars were initially immersed for the measures to be made at the buccal furcation. After all the measurements were performed, teeth were removed from the resin. The same procedure was repeated for measurements at the mesial furcation and afterwards at the distal one.

In order to immerse the teeth in resin, a $1.0 \mathrm{~cm}$ thick aluminum matrix was used, with an external measure of $4.0 \times 4.0 \mathrm{~cm}$, containing a central opening of $3.0 \times 2.0 \mathrm{~cm}$. The inner walls of the matrix were built with a divergence of 5 degrees to facilitate the removal of the resin block after its polymerization. Previously to each immersion, the aluminum matrix was fixed upon a plane glass plate. This way, the basis of each block was perfectly plane and smooth.

Fluid acrylic resin was poured inside the central opening of the aluminum matrix and each tooth was previously coated to be positioned inside the resin at the initial phase of polymerization. Immediately after this procedure, the set consisting of the glass plate, matrix and immersed tooth was taken to a specimen positioner - Karl Zeiss - to perform the leveling of the tooth before the resin initiated its final phase of polymerization.

Once the resin/tooth blocks were obtained, the limits and reference points for the measurements were determined. Marks corresponding to the limits of the root surfaces in relation to each furcation to be measured were made with the use of a surveyor with articulate shanks and a device for graffiti fixation (Bio Art Equipamentos Odontológicos Ltda., São Carlos, Brazil).

The surveyor table was leveled with the help of a precision level (Stanley). The table was fixed and remained in a horizontal position without any alteration. Thus, with the graffiti touching the tooth root tangentially, the tracing of the limits corresponding to the root surfaces was carried out.

In order to make the tracings related to the measurements of the three dental furcations, the following method was established:

- Buccal furcation (F1): tracings were made on the mesial surface of the mesio-buccal root and the distal surface of the disto-buccal root.

- Mesial furcation (F2): tracings were made on the buccal surface of the mesio-buccal root and the palatal surface of the palatal root. 
Porciúncula HF, Porciúncula MM, Zuza EP, Toledo BEC. Biometric analysis of the maxillary permanent molar teeth and its relation to furcation involvement. Braz Oral Res 2004;18(3):187-91.

- Distal furcation (F3): tracings were made on the buccal surface of the disto-buccal root and the palatal surface of the palatal root.

High precision appliances were used for the measurement phase, such as: a microscope Leica MZ6 (Leica microsystems, Glattbrugg, Swiss), with a plane objective $(1.0 \mathrm{X})$, ocular $(10 \mathrm{X})$, zoom (0.63), with a final magnification of $10.63 \mathrm{X}$; and a transilluminator with optic fibers (Intralux-4001). Assembled to this magnifying glass, a video camera DXC-107 A/107 AP - Sony (Electronics Inc., Japan) was connected to a microcomputer $486 \mathrm{DX}$ $66 \mathrm{MHz}$, in which a software for image analysis was installed (Mocha - Jandel Scientific SigmaScan Pro, version 2.0, San Raphael, California, USA).

A millimetered paper sheet, formerly gauged with the aid of the magnifying glass Leica with a precision ruler for microscopic measurements (Wild), was positioned on each tooth, upon the root trunk surface, so that its horizontal lines would be paralleled to the graphite tracing previously made on the dental crown, slightly below the cementoenamel junction (CEJ).

The image was frozen with the furcation area, the millimetered paper and the dental surface limits completely distinctive (in focus). From these images, the procedures for measuring the proposed distances started. Each distance established by the sliding of the arrow was automatically converted into a numeric value expressed in "pixels" by the software used. All the numeric values expressed by the software in number of "pixels" were converted into millimeters, considering two decimal digits.

After the measurements desired were made, the statistical analysis phase started. The average, standard deviation, confidence interval (inferior and superior limits), and the lower and the higher values found for the distances measured were separately calculated for each of the two groups of maxillary molar teeth. The mean distances obtained with the measurements furcationroot surface were compared, being performed with confidence intervals of 95\%, using the Student's $t$-test.

The comparison among the percentages obtained for the equality frequency occurrence was performed using the chi-squared test $\left(\delta^{2}\right)$. The decision rule established for this comparison process was defined using the probability (p) of significance of the equality tested, as follows: if $\mathrm{p}$ was higher than the level of significance of 0.05 , the value observed $\left(\delta^{2}\right)$ would be considered non-significant and the equality between those percentages would
TABLE 1 - Measures of the distances. Averages and confidence interval limits of distances F1M, F1D, F2B, F2P, F3B and F3P, according to buccal, mesial and distal furcations, respectively, of first maxillary molars (in millimeters).

\begin{tabular}{|c|c|c|c|c|}
\hline $\begin{array}{l}\text { Tooth/ } \\
\text { distance }\end{array}$ & Average & $\begin{array}{l}\text { Inferior } \\
\text { limit }\end{array}$ & $\begin{array}{l}\text { Superior } \\
\text { limit }\end{array}$ & $\begin{array}{l}\text { Group } \\
\text { average }\end{array}$ \\
\hline $1_{\mathrm{F} 1 \mathrm{M}}^{\text {st }} \operatorname{molar}(16)$ & 3.78 & 3.70 & 3.85 & \multirow{2}{*}{3.78} \\
\hline $1_{\text {F1M }}^{\text {st }}$ molar $(26)$ & 3.78 & 3.69 & 3.88 & \\
\hline $1_{\text {F1D }}^{\text {st }}$ molar $(16)$ & 3.57 & 3.47 & 3.67 & \multirow{2}{*}{3.62} \\
\hline $1_{\text {F1D }}^{\text {st }}$ molar $(26)$ & 3.66 & 3.56 & 3.76 & \\
\hline $\begin{array}{c}1^{\text {st }} \operatorname{molar}(16) \\
\text { F2B }\end{array}$ & 7.25 & 7.10 & 7.39 & \multirow{2}{*}{7.33} \\
\hline $1_{\text {F2B }}^{\text {st }}$ molar $(26)$ & 7.40 & 7.22 & 7.58 & \\
\hline $1_{\text {F2P }}^{\text {st }}$ molar $(16)$ & 4.10 & 3.98 & 4.21 & \multirow{2}{*}{4.13} \\
\hline $1_{\text {F2P }}^{\text {st }}$ molar $(26)$ & 4.16 & 4.03 & 4.29 & \\
\hline $1_{\text {F3B }}^{\text {st }}$ molar $(16)$ & 5.65 & 5.48 & 5.81 & \multirow{2}{*}{5.61} \\
\hline $1_{\text {F3B }}^{\text {st }}$ molar $(26)$ & 5.57 & 5.42 & 5.72 & \\
\hline $1_{\text {F3P }}^{\text {st }}$ molar (16) & 4.63 & 4.54 & 4.73 & \multirow{2}{*}{4.73} \\
\hline $1_{\text {F3P }}^{\text {st }}$ molar $(26)$ & 4.83 & 4.69 & 4.98 & \\
\hline
\end{tabular}

16 and 26: respectively, first maxillary right and left molars.

be accepted. In case the opposite occurred, the value observed $\left(\delta^{2}\right)$ would be considered significant and the equality between those percentages would be rejected.

\section{RESULTS}

Table 1 shows the averages and the limits of the confidence interval of the distances from the buccal furcation to the mesial (F1M) and distal (F1D) surfaces of the mesio-buccal and disto-buccal roots, respectively; from the mesial furcation to the buccal (F2B) and palatal (F2P) surfaces of the mesio-buccal and palatal roots; and from the distal furcation to the buccal (F3B) and palatal (F3P) surfaces of the disto-buccal and palatal roots.

The relation among distances showing the comparison of frequency between $\mathrm{F} 1 \mathrm{M}$ and $\mathrm{F} 1 \mathrm{D}$; 
Porciúncula HF, Porciúncula MM, Zuza EP, Toledo BEC. Biometric analysis of the maxillary permanent molar teeth and its relation to furcation involvement. Braz Oral Res 2004;18(3):187-91.

TABLE 2 - Relation between distances. Frequency of comparison between F1M and F1D; F2B and F2P; F3B and F3P on buccal, mesial and distal furcations, respectively, for first maxillary molars (in millimeters).

\begin{tabular}{l|r|r|r|r|r}
\hline \hline \multirow{2}{*}{ Comparison } & \multicolumn{2}{|c|}{16} & \multicolumn{2}{c|}{26} & $\mathrm{G}$ \\
\cline { 2 - 6 } & $\mathrm{N}$ & \multicolumn{1}{c|}{$\%$} & $\mathrm{~N}$ & \multicolumn{1}{c}{$\%$} & \multicolumn{1}{c}{$\%$} \\
\hline $\mathrm{F} 1 \mathrm{M}>\mathrm{F} 1 \mathrm{D}$ & 35 & 70.0 & 33 & 66.0 & 68.0 \\
\hline $\mathrm{F} 1 \mathrm{M}=\mathrm{F} 1 \mathrm{D}$ & 0 & 0.0 & 1 & 2.0 & 1.0 \\
\hline $\mathrm{F} 1 \mathrm{M}<\mathrm{F} 1 \mathrm{D}$ & 15 & 30.0 & 16 & 32.0 & 31.0 \\
\hline F2B $>$ F2P & 50 & 100.0 & 50 & 100.0 & 100.0 \\
\hline F2B $=$ F2P & 0 & 0.0 & 0 & 0.0 & 0.0 \\
\hline F2B $<$ F2P & 0 & 0.0 & 0 & 0.0 & 0.0 \\
\hline F3B > F3P & 50 & 100.0 & 44 & 88.0 & 94.0 \\
\hline F3B = F3P & 0 & 0.0 & 0 & 0.0 & 0.0 \\
\hline F3B < F3P & 0 & 0.0 & 6 & 12.0 & 6.0 \\
\hline \hline
\end{tabular}

16 and 26: first maxillary right and left molars, respectively. $\mathrm{N}$ : number of first maxillary molars (16 and 26). \%: percentage of occurrence for teeth 16 and 26 and for the groups $(G=16$ and 26).

F2B and F2P; F3B and F3P and the buccal, mesial and distal furcations, respectively, of the first maxillary molars can be observed on Table 2 .

\section{DISCUSSION}

Concerning the measurement methodology, it was verified in the related literature that some authors ${ }^{1,4}$, in order to study the variations of root morphology in different dental groups, immersed the teeth in resin blocks which were transversely sectioned afterwards.

In the present research, the measures of the distances of buccal, mesial and distal furcations from root surfaces were as precise as possible, for these measures purposed to contribute as a clinicians' guide in planning and performing periodontal/prosthetic treatments.

The distance F1M from the buccal furcation showed averages considered statistically equal in all maxillary molars; for the right and left first molars they had a similar value of $3.78 \mathrm{~mm}$ (Table 1).

The distance F1D also showed averages considered statistically equal; for the right first molars, the average was $3.57 \mathrm{~mm}$ and for the left first molars it was $3.66 \mathrm{~mm}$, leading to an average of $3.62 \mathrm{~mm}$ (Table 1). In 70\% of the cases for the right first molars and in $66 \%$ for the left first molars $\mathrm{F} 1 \mathrm{M}>\mathrm{F} 1 \mathrm{D}$, leading to a mean occurrence of $68 \%$
(Table 2). In $30 \%$ of the cases for the right molars and in $32 \%$ for the left molars F1M $<$ F1D, with a mean occurrence of $31 \%$ (Table 2).

Considering the mesial furcation (F2), the mean distance F2B for the maxillary right first molars was $7.25 \mathrm{~mm}$, for the left molars it was $7.40 \mathrm{~mm}$; the average was $7.33 \mathrm{~mm}$ (Table 1).

The average distance F2P was, respectively, $4.10 \mathrm{~mm}$ and $4.16 \mathrm{~mm}$ for the right and left molars, with an average of $4.13 \mathrm{~mm}$ (Table 1). In $100 \%$ of the cases F2B > F2P (Table 2).

When assessing the distal furcation (F3), for the distance F3B the averages found were $5.65 \mathrm{~mm}$ for the right and $5.57 \mathrm{~mm}$ for the left molars, being statistically equal with an average of $5.61 \mathrm{~mm}$ (Table 1). The averages found for the distance F3P were $4.63 \mathrm{~mm}$ for the right and $4.83 \mathrm{~mm}$ for the left molars; they were statistically equal (average of $4.73 \mathrm{~mm}$ ) (Table 1).

In $100 \%$ of the cases for the right molars and in $88 \%$ of the cases for the left molars F3B > F3P, with a mean frequency of $94 \%$ (Table 2).

Although this furcation is more often displaced to the lingual surface, its opening was closer to the center of this surface, due to the smaller dimensions of the distal surface. This finding is in accordance with Mardam-Bey et al. ${ }^{9}$ (1991), who described the distal furcation of the first maxillary molars as localized in the middle section of the tooth.

Finally, in order to obtain a relation between all these numbers and the clinical practice, some considerations must be made. In regard to the fact that in some periodontal treatments rhizotomies are carried out, Majzoub, Kon ${ }^{7}$ (1992) reported that after the removal of the disto-buccal root, the remainder anatomy is almost always unfavorable, for it features a distal concavity with a difficult access to be cleansed.

Researches ${ }^{5,10}$ showed that a loss of insertion of $2.0 \mathrm{~mm}$ is enough to cause an exposure of the pre-furcation, which becomes a retention notch for bacterial plaque. Conde et al. ${ }^{2}$ (1995) and de los Rios et al. ${ }^{3}$ (2002) emphasized that preventive treatments on the root trunk must be performed, with the purpose of exposing retention notches. The main aim of interfering in these areas to prevent from a predisposing factor, is to maintain periodontal support and to prevent furcation lesion.

Recognizing the importance of precociously identifying the presence and the extension of the 
Porciúncula HF, Porciúncula MM, Zuza EP, Toledo BEC. Biometric analysis of the maxillary permanent molar teeth and its relation to furcation involvement. Braz Oral Res 2004;18(3):187-91.

destruction of adjacent supporting tissues, or of furcation areas, the results of the present paper, in which these regions were thoroughly measured, may efficiently contribute to diagnosis, prevention and treatment of periodontal problems.

\section{CONCLUSIONS}

Gathering the values found for the distances from buccal, mesial and distal furcations to the respective surfaces of dental roots, it was possible to state the following:

\section{REFERENCES}

1. Booker BW $3^{\text {rd }}$, Loughlin DM. A morphologic study of the mesial root surface of the adolescent maxillary first bicuspid. J Periodontol 1985;56:666-70.

2. Conde MC, Carvalho JCM, Marinho JE, Pustiglioni FE, Kon $\mathrm{S}$, Tristão GC, et al. Anatomical features of the first upper molar. J Dent Res 1995;74[special issues]:174.

3. de los Rios CM, Pustiglioni FE, Romito GA. Biometric study of the width, length and depth of the root trunk groove of human lower second molars. Pesqui Odontol Bras 2002;16:26-30.

4. Dunlap RM, Gher ME. Root surface measurements of the mandibular first molar. J Periodontol 1985;56:234-8.

5. Heasman PA, Smith DG. The role of anatomy in the initiation and spread of periodontal disease: 1. Dent Update 1988;15:192-7.

6. Hou GL, Tsai CC. Cervical enamel projection and intermediate bifurcational ridge correlated with molar furcation involvements. J Periodontol 1997;68:687-93.
1. The buccal furcation, in $68 \%$ of the first maxillary molars, was displaced further to the distal surface and in $31 \%$ to the mesial.

2. In $100 \%$ of the cases, the distance measures from the mesial furcation to the buccal surface of the mesio-buccal root was longer than the distance from the mesial furcation to the palatal surface of the palatal root.

3. The distal furcation, in $94 \%$ of the teeth, was more often displaced to the palatal surface. In $6 \%$ of the first molars, this furcation was further displaced to the buccal surface.

7. Majzoub Z, Kon S. Tooth morphology following root resection procedures in maxillary first molars. J Periodontol 1992;63:290-6.

8. Mandelaris GA, Wang HL, MacNeil RL. A morphometric analysis of the furcation region of mandibular molars. Compend Contin Educ Dent 1998;19:113-6,118-20.

9. Mardam-Bey W, Majzoub Z, Kon S. Anatomic considerations in the etiology and management of maxillary and mandibular molars with furcation involvement. Int J Periodontics Restorative Dent 1991;11:398-409.

10. Smukler H, Nager MC, Tolmie PC. Interproximal tooth morphology and its effect on plaque removal. Quintessence Int 1989;20:249-55.

11. Waerhaug J. The furcation problem: etiology, pathogenesis, diagnosis, therapy and prognosis. J Clin Periodontol 1980;7:73-95. 